\title{
FATHERING STYLES OF MUSLIM FAMILIES PERCEIVED FROM PERSONALITY TYPES IN NORTH SUMATERA
}

\author{
Nurhayani \\ State Islamic University (UIN) Sumatera Utara \\ e-mail: bayani1976@gmail.com
}

\begin{tabular}{l|l|l} 
Submission: 8 May 2019 & Revised: 26 July 2019 & Published: 31 July 2019
\end{tabular}

\begin{abstract}
Fathering styles are highly influenced by the cultural background from which the father are raised. These styles will be observed by children and eventually become an imitated model for children in shaping their attitude and behaviour as well as their ethnic identity representing their cultural values. The objectives of this research are to know the difference of fathering styles between fathers in Minangkabau families and Batak families perceived from their personality types. The subjects of this research were 90 fathers in Medan, North Sumatera which consist of 45 fathers of Minangkabau ethnicity and 45 fathers of Batak ethnicity. The data of the study were collected by using two scales, which are personality types scale and fathering style scale. Analysis of Variance (ANOVA) was applied to analyze the data. The result of the analysis shows that personality types and ethnicity interact each other in affecting fathering styles ( $F: 5.872 ; \mathrm{p}=0.004<0.05$ ), so there is a difference of fathering styles between Minangkabau fathers and Batak fathers perceived from introvert and extrovert personality types. A final contribution of this study is the effort to save young generation who live fatherless and support well function families through fathers' role in transmitting good cultural values of fathers' ethnicity, so it is suggested that fathers' involvement should be existed in raising children's development any condition even divorce can not be avoided. The paternal figure should always be present in children's lives both my father's direct involvement and by the involvement of other paternal figures. The good paternal figure will help children to avoid the social problems they face in life.
\end{abstract}

Keywords: Personality types, Fathering styles, Muslim family

\section{Abstrak}

Pola pengasuban ayah tidak terlepas dari latar belakang budaya yang mempengarubi kepribadian ayah sejak. kecil. Pola pengasuban ayah akan diamati oleh anak dan menjadi model figur yang ditiru anak. dalam berperilaku dan menjadi ciri identitas etnik yang mewakili kepribadian sukunya. Penelitian bertujuan untuk mengetabui dan memahami perbedaan pola pengasuban ayah ditinjau dari tipe kepribadian pada keluarga Batak. Muslim dan keluarga Minang. Subjek penelitian adalah 90 orang ayah di Kota Medan, Sumatera Utara yang terdiri 45 orang ayah suku Minang dan 45 orang ayah suku Batak. Pengambilan data menggunakan dua skala, yaitu skala tipe kepribadian dan skala pola asuh ayah. Analisis Varians dua arah (Two Ways ANOVA) digunakan sebagai metode untuk mengalisis data. Hasil analisis data menunjukekan babwa tipe kepribadian dengan suku saling berinteraksi dalam mempengarubi pola pengasuban ayah. Kontribusi penelitian ini adalah untuk menyelamatkan generasi muda yang bidup tanpa ayah dan mendukung keutuhan fungsi keluarga melalui peran ayah dalam mentransmisi nilai budaya yang baik dari sukunya, maka disarankan agar keterlibatan ayah hendaknya diupayakan dalam kondisi apapunBerdasarkan hasil penelitian di atas, disarankan agar keterlibatan ayah dalam pengasuban anak. barus ada dalam kondisi apapun, babkan saat perceraian tak dapat dibindarkan. Figur ayah tidak boleh bilang dalam kehidupan anak baik itu dengan menghadirkan keterlibatan ayah secara langsung maupun dengan menghadirkan figur lain yang dapat melakukan peran ayah. Figur ayah yang baik akan membantu anak. terbindar dari masalah-masalah sosial yang dihadapi dalam kehidupannya

Kata Kunci: Tipe kepribadian, Pola asub, Keluarga Muslim

\section{Background}

Allah makes the main distinctions between men and women in terms of their roles and responsibilities. One of these distinctions is the creation of women with the roles to give birth to the generation of humankind. Women are created to carry out their natural roles and responsibilities just like 
men are. Therefore, Islam distinguishes roles and responsibilities between men and women, but they are equal in worship, practice, reward and punishment. It is mentioned in the Quran:

"... And due to the wives is similar to what is expected of them, according to what is reasonable. But the men have a degree over them [in responsibility and authority]." (QS. al Baqarah:228) ${ }^{\top}$

$\mathrm{Al}$ Qurthubi in the book of al Jaami'li al Kaamil Quran mentions that women have the right from men just like men who also have the right from women Allah has granted men with leadership potential such as courage, strength, the perfection of dien and intellect. These potentials are a provision for men to lead their household. Children need a "figure of heroism" from their father as they need a figure of comfort and affection from their mother' ${ }^{2}$.

A father is the one with the given responsibility to a child. According to Islamic law, fathers have an essential and noble position. They are the head of the family who leads the mother, children and servants. Fathers are responsible for them and will be asked to account for their leadership and responsibility by Allah. In the Qur'an, Luqman, Allah swears by using father-child relations. the father figure listed shows the magnitude of the father's role in educating children. father's role is equivalent to the mother's role in children's education, which differs only from the typical portion of intake, strategy and parenting style. if the role of the mother is needed as the closest person who has to give up much time to be near the child, the role of the father is few but of high quality and special. that's the style of father educating children. the gift will be firmly planted in the

1 Al-Mehri, The Quran Sabeeh International Translation (Birmingham: Islamic Publisher, 2010), p. 55.

2 Adnan Hasan Shalih al-Baharits, Tanggung Jawab Ayah terhadap Anak Laki-laki (Jakarta: Gema Insani, 1996), p. 41. heart of the child, completing the planting of values through habituation that the mother has done ${ }^{3}$.

According to some experts, there is a very strong tendency to behave in the family based on certain $\operatorname{sex}^{4}$. Although leadership potential is granted men, the concept of fatherhood leadership is not intended as an arbitrary power but as love, protection, education, guidance and humanized Being a father is not an easy role to play since there are many factors affecting men willingness to be a father, especially culturally related one. The parenting styles in Indonesian society tends to be culturally bound i.e from which cultural background the father comes from whether the patrilineal system as Batak or matrilineal system as Minangkabau. It is assumed that there are different fathering between patrilineal and matrilineal culture because such culture will influence men's personality, which in turn will also influence how they view their role as a father. The demands and expectations of both patrilineal and matrilineal systems will affect the beliefs of men in their fathering styles on their children. As a result of the study that explored the relationship between mothering, fathering and Italian adolescents' problem behaviours and life satisfaction by using both typological and dimensional approaches. From a typological perspective, it is examined variations in adolescent adjustment as a function of maternal and paternal parenting styles. The results showed that for boys, maternal and paternal strictness were negatively related to behavioral problems-both internalizing and externalizing - and positively related to general satisfaction. Meanwhile, for girls, maternal and

${ }^{3}$ Irawati Istadi, Melipatgandakan Kecerdasan Emosi Anak (Bekasi: Pustaka Inti, 2006), p. 30-31.

${ }^{4}$ Mikaela J. Dufur and others, 'Sex Differences in Parenting Behaviors in Single-Mother and SingleFather Households', Journal of Marriage and Family, 72.5 (2010), 1092-1106 <https://doi.org/10.1111/j.17413737.2010.00752.x>. 
paternal strictness was negatively related only to externalizing problems. Paternal acceptance was negatively related to girls' behavioural problems, while maternal acceptance was positively related to girls' general satisfaction ${ }^{5}$.

Culturally coding men as a father includes their rights, obligations, responsibilities and inherent status as a father as well as the dominant discourses about what defines" good "and" bad "fathers. Fathers as a man certainly have a different personality from that of woman. Their personality is influenced by their unique identities inherently manifested in the forms values, attitudes, beliefs, and goals taught in the social-cultural environment where they are and raised. Exploring fathering concept from various cultures will make us understand that fathering styles is derived from a cultural concept about a father used as an underlying principle in raising the children. How fathers play their fathering roles depend on their race, marital status, social class, and other social factors. ${ }^{6}$ However, little is known about the fathers' personality factors in influencing their fathering styles.

Fathering styles are inevitably influenced by fathers' personality formed by an inherited culture concept in which they grow. Specific attitudes and behaviours in a particular group of culture affect fathering styles. Minangkabau ethnicity is for their family system with the maternal lineage, which is certainly different from the Batak tribe who follow father lineage. These cultural differences are supposed to affect the differences in the transmission of cultural values that will also

5 Rosanna Di Maggio and Carla Zappulla, 'Mothering, Fathering, and Italian Adolescents' Problem Behaviors and Life Satisfaction: Dimensional and Typological Approach', Journal of Child and Family Studies, $23.3 \quad$ (2014), $567-80$ <https://doi.org/10.1007/s10826-013-9721-6>.

${ }^{6}$ Satu Perälä Littunen, 'Cultural Images of a Good Mother and a Good Father in Three Generations' \{unpublished doctoral thesis, Faculty of Education of the University, Jypaskyla, 2004\}, p. 69-70. affect fathers' personalities and fathering styles in each culture.

Departing from the above-mentioned issues, this study aims to explore the relationship of personality type with fathers' fathering styles in Minangkabau and Batak families. Specifically, this study will attempt to find out whether there is a relationship between personality type and fathering styles in Minangkabau and Batak families. Are there any differences in fathering styles in Minang and Batak families in terms of the father's' personality type?

This research is quantitative. The subjects of this study are ethnic Minangkabau and Batak ethnicity living in Medan. The subjects consist of 90, 45 Minangkabau ethnicity and 45 fat fathers from Batak ethnicity (Toba, Mandailing, Pakpak, Karo, Simalungun, Tapanuli). The subjects were selected through purposive sampling with the following categories and characteristics; (1) born and raised in their ethnic culture (Minangkabau/ Batak); (2) have biological teen children from their legitimate marriages; ( 3 ) at least 30 years old.

The selection of criteria for research subjects based on the above criteria is due to the following considerations; (1) Based on age factors, Carnoy and Carnoy, in his book Fathers of a Certain Age, cited in Andayani reported their observation that older fathers tend to enjoy their involvement with children, compared to younger fathers who are more focused on their identity problems ${ }^{7}$; (2) Based on the experience factor, the men have served their role as fathers in the three phases of their child's development for quite a long time, infant, childhood, and adolescent phase; (3) The criteria for subjects raised in their ethnic culture (Minangkabau/Batak) are chosen

7 Budi Koentjoro Andayani, Psikologi Keluarga Peran Ayah Menuju Coparenting, CV Mitra Media (Surabaya, 2004), p. 34. 
because the subjects are assumed to be a supporter of the culture of their ethnicity.

Data analysis in this study will be conducted by checking the data by scoring and tabulating data scores from the three scales after data collection. Then, it proceeds to the statistical processing and interpretation. This study, based on the assumptions (hypotheses), is then analyzed using two-way analysis of variance. This analysis will test the relationship between personality types and parenting styles for Minang and Batak families. After obtaining the required research data, the data are analyzed using a two-way analysis of variance techniques to test the research hypothesis.

\section{Fathering Concepts}

A father is a man deemed by society to be responsible for a child. Fatherhood is a special status given by culture when a man becomes a father which includes "rights, duties, responsibilities and status as well as problems related to "good" and "bad" father ${ }^{8}$

There are differences between the terms "father," "fatherhood," and "fathering" The term fathering signifies how fathers represent themselves when "doing" fatherhood. Fathering referred in this study is the attitude and manner of the fathers in displaying or showing their authority by giving attention and response in educating, controlling, disciplining and protecting their children based on customary norms and embedded in their culture.

However, not all men are biological fathers and not all fathers have biological children. Childcare in fathering can occur through the adoption of children to obtain legal status to give protection and responsibility for the children just like their own biological children. Men become de facto fathers when they marry women who have

\footnotetext{
${ }^{8}$ Littunen.
}

children from previous marital relationships, which are called stepchildren.

Some aspects influence how and why men are involved in the lives of their children included shared dwelling places, social class, race, masculinity, and psychological attributes and social support. First, social class influences how and why men become fathers. Fathers' income poses challenges for them in caring for their children under economic and social tension. Second, race affects how and why men make decisions to become fathers. The widely used patrilineal norm can cause fathers to have different expectations about their role. Third, masculinity affects how and why men become fathers. Masculinity interacts with the way fathers care for children. Because the behaviour of child parenting is not in accordance with hegemonic masculinity, the willingness of men to participate in childcare tasks is often limited to what psychologically can contribute to men without threatening their masculinity ${ }^{9}$. Little is known about how masculinity affects men as fathers. Do men believe that the system of matrilineal and patrilineal parenting increases or decreases their masculinity? Fourth, psychological attributes and social support affect how and why men should be good fathers. Research shows how cultural views predict that behaviours and beliefs influence parental care. Several factors influence how and why men are involved in a child's life, namely: First, social status affects how and why men involve in childcare. Income is a challenge for fathers to pay attention to their social conditions and demands. Second, ethnicity influences how and why men make decisions to become fathers because every family norm still carries its own culture. The norms of both patrilineal and matrilineal families require fathers to have

9 Jae Yung Kwon and others, 'Heterosexual Gender Relations and Masculinity in Fathers Who Smoke', Research in Nursing and Health, 37.5 (2014), 391$98<$ https://doi.org/10.1002/nur.21614>. 
different expectations based on their role as fathers. Third, masculinity has an impact on how and why men involve in childcare. Although according to parental involvement does not affect masculinity because psychological matters often limit the desire of men to take part in childcare tasks without feeling their masculinity threatened. However, there is still little research on how masculinity influences how men act as fathers. Fourth, psychosocial attributes and social support affect how and why men involve in childcare ${ }^{10}$.

Without awareness and acceptance of their own cultural values, individual may suffer from "cultural myopia," so they fail to perceive the cultural differences between themselves and those in other groups.

Fathers can individually construct on what they should do as good fathers by comparing their self-concept as fathers, along with cultural concepts about good fathers. There is an exchange between personal experience in the culture and knowledge shared according to the adopted care system. According to McAdoo, cultures differ worldviews in perspective on the rhythms and pattern of life and concepts. The impact of culture is apparent in personality and behaviour, in patterns of social interaction and in a social institution. Ethnicity reveals itself in the customs, ritual, values, attitude and personality types of individual. ${ }^{11}$

A father in a patriarchal culture in the era of Freud was described as a figure with full power and frightening for children so that in an effort to avoid punishment from the father, the child embraces the values of the father. Freud with his psychoanalytic theory, he said that children's morality in the phallic phase is shaped because of the child's relationship with his father. In other words, children internalize

${ }^{10}$ Kwon and others.

${ }^{11}$ Harriette Pipes and Mc Adoo, Family Ethnicity : Streght in Diversity, $2^{\text {nd }}$ edition (California: Sage Publication, Inc., 2015), p. 4. both good and bad values (ideal ego) and about right and wrong (conscience) based on fear. But it is different in moslem families, both men as father and woman as mother and children have rights, role, and responsibilities. Islam is a belief of system in family life that plays a vital role in promoting togetherness in family life to reduce conflict. Islam is a religion of rules. A way of life because it guides in every aspect of life. Those guidelines help resolve conflicts between parents, between husband and wife, father and children in almost every aspect ${ }^{12}$.

Parenting is certainly related to culture. Every culture is characterized, and distinguished from other cultures, by deeprooted and widely acknowledged ideas about how one needs to feel, think and act as an adequately functioning member of the culture. In so far as parents subscribe to particular conventions of culture, they likely follow prevailing "cultural scripts" in childrearing ${ }^{13}$.

In Javanese culture, described by Koentjaraningrat cited in Andayani, the relationship between children and parents, especially fathers, is characterized by obedience. It is considered impolite and inappropriate if are denied by their children. Sak kecap dha sak kecap is a negative expression to describe the disputes between parents and children $^{14}$.

During childhood, a child did not know good and evil. There was only a feeling of pleasure which encouraged him to obey the person who directed and guided him, so the child lived in the influence of the person who guided him. If the influence of the supervisor

12 Zahra Alghafli, Trevan Hatch, and Loren Marks, 'Religion and Relationships in Muslim Families: A Qualitative Examination of Devout Married Muslim Couples', Religions, $5.3 \quad$ (2014), 814-33 $<$ https://doi.org/10.3390/rel5030814>.

13 Marc H. Bornstein, 'Parenting and Child Mental Health: A Cross-Cultural Perspective', World Psychiatry, 2013 <https://doi.org/10.1002/wps.20071>. 14 Andayani. 
and director is absent, the child will grow in a weak, unmotivated, and personal doubt. Allah says in the Quran:

"And [mention, O Mubammad], when Luqman said to his son while he was instructing him, "O my son, do not associate [anything] with Allah. Indeed, association [with bim] is a great injustice." (QS. Luqman:13) ${ }^{15}$

Fathers' in controlling anger is an important factor because children will learn to control emotions from their father. Besides, fathers must avoid everything that causes anger to the child and protect from the cause of anger. According to Yusuf Saad al Hilal cited in Baharits, the causes of children's anger include; (1) Jealousy towards friends and siblings; (2) Failure in learning and achievement; (3) Harsh parental education ; (4) The loss of love feelings for children; (5) Pampering children excessively so as to encourage them to realize all their desires; (6) Imitation of parents who are often angry in front of their children; (7)Suffering from one physical disorder ${ }^{16}$

Wise fathers will know the limits of their children's ability, so as not to burden them with ethics and manners beyond it. If children make a mistake, such as anger, fathers must be patient to deal with it and not scold them because it will have bad consequences and trauma to the children.

Child factors cannot also be ignored in fathering styles. Marsaglio in Andayani, found that fathers tend to be more comfortable interacting with boys than girls. Marsaglio suspected this is because boys identify themselves with their fathers, and father-child communication becomes easier.

As a male, fathers have a personality that can generally be said to be different from women. The process of socialising childhood will play a huge role in this matter. Therefore,

${ }^{15} \mathrm{Al}-\mathrm{Mehri.}$

${ }^{16} \mathrm{Al}-\mathrm{B}$ aharits. what is called "sexual role" arises to distinguish the roles of men and women.

The problem arising today related to the presence of psychosocial lag between changes in the role of men in families, which is slow, compared to changes in the role of women, which is relatively faster. As predicted by the perspective of role change, in the 21 st-century men began to play a greater role in household tasks and care. Its emphasize the importance of the involvement of fathers in parenting, especially in terms of developing children's emotional intelligence.

Essentially, fathers' personality will influence their strategies in educating their children. Some important aspects related to fathers' personality are; (1) Exemplary. There is an inherent tendency in children to imitate the things around it. The child considers everything their parents do as a right and good thing. Hence, the child will imitate them. The process of imitation comes from the love of a pure child to his father. Based on this fact, Freud's concept of oedipus complex a child (male) bear hatred and anger towards his father because he adored his mother very much is not accurate. This is certainly contrary to the nature of children who are still pure. Father's psychological tendencies also become a child's tendency; (2) Affection and love Fathers' love is a nature that must be expressed in children's education. Children who capture their fathers' hatred will make mistakes that make them upset; (3) Fairness Being fair in certain circumstances sometimes has difficulties because of the limitations of the fathers in controlling themselves, and the child is very sensitive to changes in behaviour towards him ${ }^{17}$.

Fathers' attitude, temperament, characteristics and behaviour influences the strategies they choose in educating their children in the form of exemplary, affection

\footnotetext{
17 Al-Baharits.
} 
and love, and fairness. The study Noviati who explored the parenting strategy by single mothers and single fathers inform ethical behaviour of adolescents relationships in the upper-middle-class family. Parenting strategies by a single mother is a small threat. Parenting strategies by a single father in terms of the parenting model is divided into two, namely: the architect model and a farmer model. Parenting strategies by a single father with an architect model is habituation and discipline. For parenting strategies by a single father with a farmer model is habituation and real action ${ }^{18}$.

The absence of a father, mothers, cannot be assertive or have any power over their children is problematic as Lisnani's research shows that the highest percentage (63.3\%) with the category of negative self-concept in divorced family mothers is on the dimensions of emotional stability. Emotional stability is the mother's assessment of their emotional ability to feel calm, relaxed, stable and the ability to manage anxiety ${ }^{19}$. when mothers are in a state of stress, tend to produce negative parenting behaviours and styles and interactions that are oriented towards lack of acceptance $^{20}$. It is mean that fathers have a direct and indirect role in parenting. Indirectly, the fathers act as a supporting partner to improve mothers' nurturing abilities while directly fathers' role encourages the level of the emotional attachment of children from an early age. As the study showed that fathers absence during childhood and divorce of

18 Noviati, 'Strategi Pengasuhan Anak oleh Ibu Tunggal dan Bapak Tunggal Mengembangkan Perilaku Etis Pergaulan', Jurnal Kajian Moral dan Kewarganegaraan, 2.3 (2015), 1-15.

${ }^{19}$ Lisnani Sukaidawati, D.K. Pranaji, and Ratna Megawangi, 'Konsep Diri Ibu dan Remaja pada Keluarga Cerai dan Utuh', Jurnal Ilmu Keluarga dan Konsumen, 2016

<https://doi.org/10.24156/jikk.2016.9.1.11>.

20 Sukaidawati, Pranaji, and Megawangi. parents affect the future quality of fathering of their sons negatively. ${ }^{21}$

Therefore, the presence of a father is the mother's need for his role in interacting with the child. there is not much data that states that children whose care is dominated by mothers experience serious problems, or conversely children whose care is dominated by fathers. But a mother who handles all household affairs and child problems, not to mention the problem of taking care of a family who is sick or has economic problems. Then a mother will experience considerable stress. This condition will affect the way the mother approaches the child. According to Gottman and DeClaire cited in Andayani the male style of a father will provide an opportunity for developing emotional intelligence in children ${ }^{22}$.

Parenting competencies are determined by some factors. Contextual support and stress can, directly and indirectly, influence parental care by influencing the psychological well-being of the individual which in turn results in various ways of nurturing. Parenting is also influenced by various factors, namely personality (which is influenced by the history of individual development), conditions that provide support or stress from the work environment, marriage and other social conditions. From this model, it seems that the factors affecting individual personality in childcare can be said as a complicated process.

Fathers often apply harsh discipline, for example, they are generally known to have more power assertive than that of mothers. Mothers' need for the role of the father. Without a father, they cannot be expected to have a power assertive. The study found that

${ }^{21}$ Ruth Depaiva, 'Quality of Fathering and Its Relationship with Family Background, Demographics, and Characteristics of Present Family: A Study of Seventh-Day Adventist Fathers and Fathers From a National Sample' \{unpublished doctoral thesis, Andrews University School of Education, New York, 1998), p.102.

$$
22 \text { Andayani. }
$$


boys without fathers reported that their mothers revealed less affection than boys who had fathers, but different from girls, the absence of fathers had little effect on social and emotional development. There are different patterns regarding the influence of fathers' absence on boys and girls. Based on Hetherington's findings cited in Dagun showed that the influence in girls arises when adolescents appear to be unable to interact appropriately with the opposite sex. This causes fear, inadequate skills, and feelings of insecurity, anxiety, and helplessness in dealing with male ${ }^{23}$ Dagun states that father-child relationships are the basis of romantic attachment to girls. He claimed that a woman's capacity to have an attachment in love and sex is related to how close she is to his father. ${ }^{24}$

This is in line with one of the main theoretical perspectives on sex differences in shaping behaviour, namely the perspective of the learning process theory, which emphasizes the existence of processes in the formation of behaviour such as strengthening and imitation of a person obtaining permanent characteristics related to sex. Parents through actions and examples influence boys and girls to adjust to moral norms in their cultural environment ${ }^{25}$.

Every parent is different in their beliefs about the innate nature of children and acceptable and unacceptable behaviour. Parents differ not only in their beliefs about the innate nature of children but also in their beliefs about acceptable and unacceptable behaviour. It turns out that it is easier for fathers to accept differences in children and considers "difficult temperament" in the mothers' perception as something natural. The specific factor of children according to Belsky

\footnotetext{
23 Save M. Dagun, Psikologi Keluarga (Jakarta: Rineka Cipta, 2013), p. 90.

${ }^{24}$ Dagun.

25 David C. Sears, Jonathan L. Freedman, Psikologi Sosial (Jakarta: Erlangga, 2001), p. 40.
}

cited in Andayani is a factor that is no less important in the form of fathers' involvement. Children who are perceived by mothers as "difficult" children will receive different treatment from children who are perceived as sweet children ${ }^{26}$.

Fathers involved and sensitive in parenting will have a positive effect on children's development. When fathers are involved and discipline, it will reduce the tendency of children to behave disturbingly (angry, stubborn, deviant behaviour), especially during school.

Father involvement will also develop a children's ability to empathise, be attentive and affectionate and better social relationships. Research also shows that father involvement will provide positive benefits for boys in developing self-control, in the ability to delay gratification of desires and in the social adjustment of male adolescents. Although the research has not provided strong support for the role of fathers, it is believed that the father's involvement and sensitivity in care will provide significant benefits for the development of girls. In the development of a daughter, affection and affective attention from the father are very needed. Gottman and DeClaire cited in Andayani, underline that although strong research results have not supported father's role in women's academic and career achievements, girls who are accompanied by their father will tend not to be promiscuous sexually early and able to develop healthy relationships with men in their adult life. Girls who get positive attention from their father will get the fulfilment of affective wholeness and at the same time will learn how to deal with the opposite sex healthily ${ }^{27}$.

Fathers tend to act differently towards boys and girls following the prevailing cultural values in their society. As an adopting parent,

\footnotetext{
26 Andayani.

27 Andayani.
} 
fathers have certain behavioural expectations according to their children's sex that allows boys and girls to get the opportunity for different roles. This is in line with the theory of social learning that children learn to behave in accordance with gender behaviour through observation and imitation of differences in parental treatment. Girls will observe behaviour expected by parents according to their gender roles and so do boys. However, a particular environment will have different influences depending on the tendencies of boys and girls to build their own version of behaviour patterns actively. In everyday life, boys and girls use their basic talents and drives in ways that are related to gender.

Women's emotions according to Archer, 1996 tend to be bigger than that of men and girls generally tend to be less assertive or easily hesitated and have anxiety. Girls have emotional responses that are different from boys when experiencing tension ${ }^{28}$. According to Campbell cited in Wolfe, anger in girls is accompanied by emotions such as fear, anxiety, guilt and shame; whereas anger in boys is characterized by tantrums or opposing values in their social environment. When angry, girls tend to blame themselves because they worry that their anger will harm others and damage relationships with others ${ }^{29}$. Authoritative fathers who show sympathy, warmness and support will help girls manage emotions effectively. Thus, the impact of the emotional experience that children get from childhood from father figures influences their ability to control their emotions; Hence, if fathers support children's emotional development by becoming a model figure who

28 John Archer, 'Sex Differences in Social Behavior: Are the Social Role and Evolutionary Explanations Compatible?', American Psychologist, 51.9 (1996), 909-17 <https://doi.org/10.1037/0003066X.51.9.909>.

29 Anne Wolfe, Women and Crime, Science News (Macmillan International Higher Education, 1975), CVIII <https://doi.org/10.2307/3960173>. can control emotions healthily, children will be able to achieve emotional maturity as male and female.

In each culture, men and women receive different treatment and demands that are quite striking. Boys and girls receive different views and expectations. Such views and expectations influence parenting styles. The research of Christopher G. Sansone cited in Rahman found that racial and ethnic backgrounds influence the way fathers applied parenting. Fathers who have ethnic awareness will consider how their parenting style will shape ethnic identity in children so that they form a sense of belonging and form cultural competence in their children's identity ${ }^{30}$.

Division of sex roles related to what things can be done and who can do them also influence the understanding of the participation of each sex in social life. Thus, when there is an imbalance of the roles obtained from the status between boys and girls, it will affect cognitive and affective differently between boys and girls which ultimately affects the development of moral emotions and moral reasoning.

The habitual experience that children receive through parents in treating, educating, controlling, disciplining and protecting them is inseparable from the traditional background factors of a community. Culture influences men when acting as ideal fathers according to the customs they believe in. Fathering styles in treating, educating, controlling, disciplining and protecting children is considered to have a relationship with the father's personality due to the parenting system adopted by the culture in which the father was raised.

30 Putri Rahman and Elvi Yusuf, 'Gambaran Pola Asuh Orangtua pada Masyarakat Pesisir Pantai', Predicara, 1.1 (2012), 12-26. 
The Correlation between Personality Types and Fathering in the Minang and Batak Families

In each culture, men and women receive different treatment and demands. This will influence parenting styles. Racial and ethnic backgrounds influence the way fathers applied parenting and they will consider how their parenting styles based on their ethnic awareness. Ethnic awareness forms their ethnic identity and becomes the father's personality. Based on statistical calculations through the two-way variance analysis, it obtains the correlation between the personality types and fathering styles with a significance value of $0,000<0.05$.

Based on Test of Subject Effects, it has been found; (1) The correlation between fathering styles and ethnicity with a significant value of ethnicity $0,045<0,05$. It can be concluded that fathering styles correlated to ethnicity (Bataknese and Minangnese); (2) The correlation between fathers' personality types and fathering styles and with significant value of $0,000<0,05$. It means that fathers' personality types correlated to fathering styles; (3) The correlation between ethnicity and personality types with a significant value 0,004 $<0,05$. It means that there was a significant correlation between ethnicity (Batak and Minang) and father's personality.

Based on Survey was conducted to 90 fathers (split between Minangkabau and Batak) by using three scales, they are fathering styles scale and personality types scale. Fathering styles scale is compiled based on 6 dimensions of the fathering scale practice proposed. The components measured by the scale in this study are awareness, consistency, protecting, active listening, respect for their mother's child (respecting child-mother), involvement. This scale consists of 38 items. The personality type scale is intended to collect data about the father's personality type that is displayed in his role as a father. This study uses a personality type scale compiled with reference to the theoretical which distinguish personality types from extrovert and introvert personality types. Someone who shows the extrovert personality type has the characteristics of being sociable, responsive to the environment, friendly, relaxed, passionate, cheerful, impulsive, obedient to heart encouragement, following changes, easily aroused and affected, aggressive, easily agitated, risk-taking, expressive, practical and unable to be responsible. While someone who has an introverted personality type will show characteristics of being less sociable, quiet, pessimistic, calm, rigid, moody, easy to worry, his emotions flat, often doing his activities, be careful in making decisions, being able to resist, reflective and responsible. In this study, personality type variables were measured on an extrovert-introvert scale that had been adapted from the scale of Kuntadi. Kuntadi explore that the components measured by the scale in this study are: (a) activity, (b) sociability (c) risk-taking, (d) impulsiveness, (e) expressiveness (f) reflectiveness (g) responsibility. This scale consists of 30 items consisting of 19 favourite items and 11 items that are unfavourable, with five alternative answers $^{31}$.

From these theories, the blueprint was compiled and then developed into items. On the scale of father's parenting pattern is composed of 38 items, while the scale of personality type is composed of 55 items. Next is the reliability test and the validity of the gauge in $20 \%$ of the total number of subjects. The results of the measurement test showed that there were a number of deaths (could not be used. On the scale of the 6 parenting pattern, the items used on the scale

${ }^{31}$ Heru Kuntadi, 'Gaya Pengambilan Keputusan Ditinjau Dari Tipe Kepribadian’ \{unpublished magister thesis, Fakultas Psikologi Universitas Gajah Mada, Yogyakarta, 2004\}, p. 12. 
were 32 items. While the scale of the personality type was 36 items, there were 19 items that were dropped.

This study, based on the assumptions (hypotheses) which are then analyzed using two-way analysis of variance. This analysis will test the relationship between personality types and parenting styles for Minang and Batak families. Data analysis in this study was carried out by multiple comparison analysis (Multiple Comparison Analysis) and two ways ANOVA test. The entire data computation was done with the Statistical Package for Social Science (SPSS) program for Windows Release 16.0.

Based on a statistical analysis of the sample, $\mathrm{H} 0$ is rejected and $\mathrm{H} 1$ is accepted, meaning there is a relationship between the personality type and fathering. Regarding the relationship of fathering styles based on ethnicity, it is obtained a significance value (2tailed) of 0.045 and $>0.05$. Thus $\mathrm{HO}$ is accepted and $\mathrm{H} 1$ is rejected, so it can be concluded that there is an ethnicity relationship with the fathering styles. Thus, the hypothesis that there is a relationship between the personality type and fathering style is accepted.

According to Geertz cited in Poerwanti, human behaviour as a member of society will be bound by culture, which can be seen in various institutions that function as a control mechanism for this behaviour. The values contained in culture are a reference for human attitudes and behaviour as individual beings that are inseparable from their relation to others with their distinctive cultural orientation. Each ethnic group has its own culture and habits which they obtain from generation to generation from their respective groups. $^{32}$

\footnotetext{
32 Endang Poerwanti, Pemahaman Psikologi Masyarakat Indonesia Sebagai Upaya Menjembatani Permasalahan Silang Budaya (Malang: Lembaga Kebudayaan-Universitas Muhammadiyah Malang, 2006), p. 34
}

Human individuals are dynamic in their society and culture. Their personality development in society is faced with behavioural models that are sometimes rewarded and agreed upon by several groups but disapproved by other groups. Each culture has a different standard of behaviour. Culture will shape the personality of a child who is developing from existing conditions. A personality becomes a persons' personal identity if their entire psychophysical systems including talent skills, activity, characteristics express their distinctiveness in adjusting themselves to their cultural environment.

Individuals seek to recognize their identity and other people will also claim to be an identity of a particular ethnic group. The formation of ethnic identity is through a long and complex process from one generation to the next which forms a distinctive individual attitude. ${ }^{33}$ Individuals tend to accept and trust what is conveyed in their culture and tend not to accept and ignore what is contrary to their cultural values. This is what will affect the distinctiveness of individual personalities based on their ethnic culture. Cultivating cultural values is done through instilling habits that will accumulate into one's personality.

Fathers' personality is influenced by their cultural values where they are raised, so they will have a tendency to act and adapt parenting styles with certain behavioural expectations based on the cultural values adopted. Fathers' personality will influence the pattern of care through the strategies chosen by the father in treating, educating, controlling, disciplining and protecting the children. Customary culture of a society influences the differences in men when acting as ideal fathers according to the customs they believe in.

\footnotetext{
33 Poerwanti.
} 
Differences in Fathering Styles in Terms of Personality Types in the Minang and Batak Families

Fathers as a man from a certain ethnic group adopt typical fathering styles in accordance with the standards of cultural expectations that shape their personality. Information about ethnic characteristics inherent in an ethnic identity personality greatly determines whether individuals identify themselves as an ethnic member and then confirms their ethnic identity. Each of father's ethnic identity effect to be personality which has a standard of behaviour based on the cultural environment. Thus, each father will give parenting styles based on the standard of behaviour that is absorbed from fathers both Batak and Minangkabau.

The difference in parenting style in terms of personality types obtained significance value of $0000<0.05$. It can be seen as follows:

Table 1. Post Hoc Multiple Comparisons of Fathering Styles

\begin{tabular}{|c|c|c|c|c|c|c|}
\hline \multirow{2}{*}{$\begin{array}{l}\text { (I) } \\
\text { personality } \\
\text { types }\end{array}$} & \multirow[b]{2}{*}{$\begin{array}{l}\text { (J) Personality } \\
\text { types }\end{array}$} & \multirow{2}{*}{$\begin{array}{l}\text { Mean } \\
\text { Differen } \\
\text { ce (I-J) }\end{array}$} & \multirow[b]{2}{*}{$\begin{array}{l}\text { Std. } \\
\text { Error }\end{array}$} & \multirow[b]{2}{*}{ Sig. } & \multicolumn{2}{|c|}{$\begin{array}{l}95 \% \\
\text { Confidence } \\
\text { Interval }\end{array}$} \\
\hline & & & & & $\begin{array}{l}\text { Lower } \\
\text { Bound }\end{array}$ & $\begin{array}{l}\text { Upper } \\
\text { Bound }\end{array}$ \\
\hline \multirow{2}{*}{$\begin{array}{l}\text { INTROVER } \\
T\end{array}$} & MEDIUM & $-11.87^{*}$ & 1.199 & .000 & -14.73 & -9.01 \\
\hline & EKSTROVERT & $-22.63^{*}$ & 1.275 & . 000 & -25.67 & -19.58 \\
\hline \multirow[t]{2}{*}{ MEDIUM } & INTROVERT & $11.87^{*}$ & 1.199 & .000 & 9.01 & 14.73 \\
\hline & EKSTROVERT & $-10.76^{*}$ & 1.085 & .000 & -13.35 & -8.17 \\
\hline \multirow{2}{*}{$\begin{array}{l}\text { EKSTROVE } \\
\text { RT }\end{array}$} & INTROVERT & $22.63^{*}$ & 1.275 & .000 & 19.58 & 25.67 \\
\hline & MEDIUM & $10.76^{*}$ & 1.085 & .000 & 8.17 & 13.35 \\
\hline
\end{tabular}

Based on Table 1, the colour of Mean Difference, it can be seen star signs and significant value at the .05 level $0,000<0,05$. It can be concluded that there is the difference and the hypothesis is accepted. Thus, there are significant differences in fathering styles in terms of personality types in the Minang and Batak families. Similarly, the hypothesis that there are differences in fathering for Minangkabau and Batak families is accepted.

Ethnic identity confirmed by fathers becomes the personality experienced in the culture in which they are raised. It is then integrated and gives a distinctive pattern to their behaviour and adjustment patterns. Hence, fathering styles in treating children have a significant relationship with fathers' personality as a result of the parenting system adopted by the culture in which they are raised. Parents become a central reference for the formation of one's personal character. If fathers are raised with an authoritarian parenting style, they tend to commit violence when fathering their children. Fathers who have an indifferent and permissive personality will tend to adopt parenting patterns in a cold atmosphere and are less familiar with their children, as Anderson says:

"Earlier socialization experiences appear to play an important role in men's and women's different approaches to parenting. Most men lack role models for parenting because they have come from families in which their fathers did not participate in the young children. Women are identified within our culture as being more responsible for parenting than men. Many women still do not expect men too much around the house or to be highly involved in childcare ${ }^{\text {c634 }}$.

Childhood experiences have a strong influence on the differences in approaches taken by men and women in childcare. According to David and Nestor, there are several reasons why parents apply parenting differently based on children's gender. First, boys and girls are different in their level of internalization. For example, since early childhood girls have higher empathy and social cognitive maturity. Second, parents use different types or levels of discipline. Third, some types of discipline are applied by parents and their effects are mediated by

34 Stephen A. Anderson, Family Interaction: $A$ Multigenerational Developmental Perspective (Boston: Allyn and Bacon, 2003), p. 2009. 
gender ${ }^{35}$. Miller's research found that when fathers are involved in parenting and applying sufficiently high discipline will reduce the tendency of children to behave externally such as anger, stubbornness and deviant behavior, especially in school. a father who has a high level of appreciation will involve himself in the process of socializing children. Expressiveness trait is one of the personalities described as tending to direct the orientation of communal oriented relations so that he will try to give his best to maintain a harmonious close relationship ${ }^{36}$.

Since their childhood, fathers have been required to be able to think calmly, hold back feelings, and resolve his emotional problems by being busy. When men have a problem, they will focus on thinking about the problem more clearly, and think of certain plans related to the problem. Men will use a more focused strategy. This is what distinguishes their from that of women when caring for children. This is in line with one of the main theoretical perspectives on sex differences in shaping behaviour, namely the perspective of the learning process theory which emphasizes the existence of processes in the formation of behaviour such as strengthening and imitation of a person obtaining permanent characteristics related to $\operatorname{sex}^{37}$.

There is a strong connection between culture and parenting. What is acceptable in one culture is frowned upon in another. This

35 David C.R. Kerr and others, 'Parental Discipline and Externalizing Behavior Problems in Early Childhood: The Roles of Moral Regulation and Child Gender', Journal of Abnormal Child Psychology, 32.4 (2004), $369-83$ $<$ https://doi.org/10.1023/B:JACP.0000030291.72775. $96>$.

36 Istianah A Rahman, 'Hubungan antara Persepsi terhadap Pola Asuh Demokratis Ayah dan Ibu dengan Perilaku Disiplin Remaja', Lentera Pendidikan: Jurnal Ilmu Tarbiyab dan Keguruan, 11.1 (2008), 69-82 <https://doi.org/10.24252/lp.2008v11n1a6>.

${ }^{37}$ Kerr and others. applies to behaviour after birth, encouragement in early childhood, and regulation and freedom during adolescence. There are differences in affection and distance, harshness and repression, and acceptance and criticism. Some parents insist on obedience; others are concerned with individual development ${ }^{38}$.

According to Pauline, fathers' behaviour is influenced by other family members. Each family member will be a behavioural model, namely as a reinforcement or inhibitor for the formation of the behaviour of other family members. For example, a baby's cry is present as a stimulus, and the parents process this stimulus in his cognitive. This cognitive process is based on the history of the learning process which can produce his personal experience of the baby crying and imitate other people's reactions to the baby's crying. When a father observes his wife's behaviour that does not respond to the baby's cries, the father will regard the wife as a woman who does not care and is not caring. Based on the socialisation of the role of traditional sex observed from the family and culture, he will think according to the scheme of life in his family, he believes that the wife do not love her baby as she was (attribution), his wife could not be a good mother (hope). I am angry with him, tired and disappointed (psychological statement). This then continues to be a problem in marriage that causes less attention to children. Next, his son made observational learning that his mother is scolded by his father. Then the son reveals his anger at the father and the father will give his full attention as best he can and try to convince him to give whatever the child wants. This

${ }^{38}$ Helaine Selin (ed.al), Parenting Across Cultures_ Childrearing, Motherhood and Fatherhood in Non-Western Cultures, Science Across Cultures: The History of Non-Western Science (UK: Spingers, 2014), p. 231. <https://doi.org/10.1007/978-94-007-7503-9>. 
pattern repeats itself and accidentally the son even learn accidentally to be coercive. In other words, this is the pattern that is learned as a child that shapes the personality of a father ${ }^{39}$.

The differences in fathering styles of Minangkabau and Batak families in terms of fathers' personality are accepted because Minangkabau and Batak fathers are influenced by the distinctiveness of their cultural identities inherent in their personality in the form of values, attitudes, beliefs, and goals taught by the socio-cultural environment. Harkness cited in Anderson mentions that cultural values are transmitted by parents to children but keep in mind that diverse values and beliefs in each culture are not deterministic, meaning cultural influences in the process parenting is very diverse depending on the situation and the individual. ${ }^{40}$ As Dumas and others found a correlation between the perceived positive parenting and the influence on the ability to convey the stories with a positive resolution. Fathering factors that were perceived to have a positive effect on identity development can lead to positive life stories. ${ }^{41}$

Not all individuals in groups of a particular culture behave the same. Every individual has a strong difference in identifying a cultural value. This is because the signals of treatment The treatment signals that aim to differentiate between men and women in society actually exist, which have then permeated since they were children, that he is a man, so he must be like this and because he is a woman he must be. This difference in treatment based on gender has

39 G. Boss Pauline (ed.al), Source of Family Theories and Methods : a Contextual Aapproach (New York: Plenum Press, 1993), p. 544.

${ }^{40}$ Anderson.

${ }^{41}$ Lacei R. Koffi, 'Adolescents' Perceptions of Fathering Factors that Influence Identity Development' \{unpublished doctoral thesis, Texas Woman's University, Denton \& Texas, 2011), p. 117. become the norm from an early age which subsequently becomes stronger and more real in social life ${ }^{42}$.

Fathers' special attitudes and behaviours in a particular group culture influence the fathering style they apply. If they are raised by families, where their fathers do not participate in parenting, then women will be considered to be more responsible for parenting than men. But sometimes, when men are actively involved in parenting, women tend to monitor the activities of men in doing care to ascertain whether men as fathers have done everything well ${ }^{43}$.

The conflict between psychological needs and people's expectations of gender roles forms a thinking pattern and feelings of fathers in certain ethnic groups to adjust to their cultural environment and to determine their willingness to be involved in childcare. Thus, the relationship of the ethnicity (Batak and Minangkabau) with fathering styles is evident in Minang culture with matrilineal cultural characteristics (kinship with maternal lines) and Batak who adhere to patrilineal culture (kinship with fatherhood). It influences the peculiarities of Minang and Batak fathers' personality in applying their fathering. In other words, the peculiarities of the fathering style of the Minangkabau and Batak families have a close relationship with the fathers' personality type which is inseparable from how the cultural influences of each ethnicity shape it. That is why there are differences in fathering style for Minangkabau and Batak families.

Typical parenting styles are influenced by local culture about the role that must be taken in caring for children as stated Brofenvreener in Santrock, cited in Rahman, care is influenced by culture, ethnicity and

42 Endang Widyorini, 'Perempuan Berbakat dalam Budaya Jawa' \{unpublished magister thesis, Universitas Gadjah Mada, Yogyakarta, 2004\}, p. 30. 43 Anderson. 
socioeconomic status ${ }^{44}$. Culture colours fathers' style in giving parenting. Fathers who think that the education given by their parents is true can make their children accepted into society well. Thus, the culture or habits of the community in caring for children also affect every father to follow the ways he does to nurture children. Edwards said that parents, especially fathers will follow the habits of the community in caring for children because these patterns are considered successful in educating children toward maturity.

The differences in the personality type of Minangkabau and Batak fathers can be observed from the personality characteristics of Minangkabau ethnicity in terms of decision making with strong determination and as well as as the ability to survive in a new environment. According to Navis cited in Suciati, Minangkabau people have a high motivation to live continuously in the achievement of glory, intelligence and wealth so that the Minangkabau people tend to be more courageous and open ${ }^{45}$. Minangkabau man ibarat abu di atas tunggul (like ash on a stum), if a wind blows, the wind will bring the ashes to fly. So too, the Minangkabau man will go merantau (leave his hometown to make a better living) because there is no place for him in Rumah Gadang (family house). Children from Minangkabau descendants tend to be brave because they are educated to be independent with their tradition of merantau. ${ }^{46}$ As a result of adopting a matrilineal family system, Minangkabau ethnicity does have a nuclear family in marriage because each husband or wife

44 Rahman.

45 Rina Suciati and Ivan Muhammad Agung, 'Perbedaan Ekspresi Emosi Pada Orang Batak, Jawa, Melayu dan Minangkabau', Jurnal Psikologi, 2017 <https://doi.org/10.24014/jp.v12i2.3236>

${ }^{46}$ Faisal Aji Purnomo, Transcultural Pola Asub di Suku Minangkabau (Semarang: Politeknik Kesehatan Kementrian Kesehatan Semarang Press, 2015), p.2. remains a member of their respective lineage. The notion of a nuclear family consisting of mothers, fathers and children as a separate unit does not exist in the Minangkabau social structure because they are centred on a stronger maternal lineage system. As a result, children are considered as members of the maternal families and always attach more to their mother and her family members. This situation weakens the ties or estranges fathers' role in the household as well as their power in regulating their family. The existence of the gap between the paternal family and children can be seen when a man does polygamy visit his children less often. The bond of fathers and children decreases when divorce occurs making them rarely meet their children. Eventually, the children do not know their father, do not his the role of a father in the family and become distant with him ${ }^{47}$.

The same characteristics are also seen in Batak ethnicity who are more likely to be expressive. Batak people are known for their physical and verbal openness, spontaneity, and aggressiveness. The personality of the Batak people is known for its tenacity, style of speaking loud, brave, and decisive. These things form from the values of Batak culture which have been adhered to and delivered from generation to generation, dalihan na tolu, meaning three-legged furnace, if one leg is damaged then it cannot be used anymore because it is not balanced. In addition, in expressing emotions in the form of behaviour, words or facial expressions Batak people have adjusted them to the strong or weak extent of those emotions. They neither exaggerate them nor sugarcoat them.

The kinship system in the Batak ethnicity is "patrilineal", in which the children follow the family line of their father. Therefore a father in the Batak ethnicity expects the birth

\footnotetext{
47 Purnomo.
} 
of a son as the successor of "tarombo" or his lineage. If a father does not have a son until the end of his life as a successor to his line, he is said to be "punu" or extinct. When having a son, there are several stages of the relationship between fathers and their son. The first stage is when the son is born until the age of 5 years old. In this stage, fathers proudly tell everyone that their son is born and take him to a crowded place like a party. After that, the "very close" relationship begins to diminish. The second stage is when their son is adolescent getting until "dolidoli", they have a very strict relationship. Fathers start "not to close" with their son. There is no "intimate" relationships anymore. Both of them are reluctant to "tell stories" especially "apologize to each other"? They begin to show their ego. The way Batak fathers express their love is often not the same as their heart. ${ }^{48}$

This personal characteristic of Minangkabau and Batak fathers causes differences in the fathering styles of Minangkabau and Batak families as well as in transmitting values to their children to be brave, decisive, open, persistent, and independent.

\section{Conclusion}

The findings of the study showed that there are significant differences in fathering styles in terms of personality types in the Minang and Batak families. Similarly, the hypothesis that there are differences in fathering styles perceived from personality types in Minangkabau and Batak families is accepted. Ethnicity and personality types have been shown to interact with each other in

48 Rintar Sipahutar, 'Hubungan yang Kaku antara Ayah dan Anak Laki-Lakinya dalam Suku Batak, Kompasiana $<$ https://www.kompasiana.com/rintar sipa hutar/5a73d31ddcad5b632e5a63b2/hubungan-kaku-antara-ayah-dan-dalam-suku-batak?page $=$ all $>\quad$ accessed 10 March 2018\} influencing fathering styles. There are differences in fathering styles of Minangkabau and Batak families both for fathers with introverted personality types and for fathers with extrovert personality types.

From the results of the research, it is recommended that all families under any circumstances even should still try to maintain the involvement of the father in any condition even when the divorce is unavoidable.

The paternal figure should not be lost in the life of the child. It should be present by involving them directly or by presenting other figures who can carry out fathers' role. Fathers' personality will be observed by the children and becomes a model emulating and forming their self-confidence in behaving according to cultural values in an ethnic environment. Good fathers will help their children deal with social adjustment problems that they encounter in their life. This happened because fathers can have a significant impact on the identity development of the adolescent. During adolescent, it is common for adolescents to explore and seek out their own beliefs. Basic principles and values are often established and adolescents rely on others for support and guidance. By Vygotsky's model of scaffolding, adolescents' perception supports the idea that fathers can provide sufficient support to promote identity development by being and providing resources, positing and communicating compelling questions and scenarios for adolescents. $^{49}$

Fathers today faced significant challenges both in their professional and personal life to pursue the balance between their traditional breadwinner role and active involvement in rearing children, so fathers who believe in the inherent value of the fathering role should

\footnotetext{
${ }^{49}$ Koffi.
} 
prepare to win their rights and the way for a new definition of fathering.

A final contribution of this study is the effort to save the young generation who live fatherless and support well function families through fathers' role in transmitting ethical, cultural values of fathers' ethnicity.

\section{References}

\section{Books}

Al-Mehri, The Quran Saheeh International Translation (Birmingham: Islamic Publisher, 2010)

Andayani, Budi Koentjoro, Psikologi Keluarga Peran Ayah Menuju Coparenting, CV Mitra Media (Surabaya, 2004).

Anderson, Stephen A., Family Interaction: A Multigenerational Developmental Perspective (Boston: Allyn and Bacon, 2003)

Baharits, Adnan Hasan Shalih, Tanggung Jawab Ayah terbadap Anak Laki-laki (Jakarta: Gema Insani, 1996)

Dagun, Save M., Psikologi Keluarga (Jakarta: Rineka Cipta, 2013)

Istadi, Irawati, Melipatgandakan Kecerdasan Emosi Anak (Bekasi: Pustaka Inti, 2006)

Pauline, G. Boss (ed.al), Source of Family Theories and Methods : a Contextual Aapproach (New York: Plenum Press, 1993)

Pipes, Harriette and Mc Adoo, Family Ethnicity: Streght in Diversity, $2^{\text {nd }}$ edition (California: Sage Publication, Inc., 2015)

Poerwanti, Endang, Pemahaman Psikologi Masyarakat Indonesia Sebagai Upaya Menjembatani Permasalahan Silang Budaya (Malang: Lembaga KebudayaanUniversitas Muhammadiyah Malang, 2006)

Purnomo, Faisal Aji, Transcultural Pola Asuh di Suku Minangkabau (Semarang: Politeknik Kesehatan Kementrian Kesehatan Semarang Press, 2015)

Sears, David C., Jonathan L. Freedman, Psikologi Sosial (Jakarta: Erlangga, 2001)
Selin, Helaine (ed.al), Parenting Across Cultures_ Childrearing, Motherhood and Fatherhood in Non-Western Cultures, Science Across Cultures: The History of Non-Western Science (UK: Spingers, 2014), p. 231. $<$ https://doi.org/10.1007/978-94-0077503-9>.

\section{Journals}

Alghafli, Zahra, Trevan Hatch, and Loren Marks, 'Religion and Relationships in Muslim Families: A Qualitative Examination of Devout Married Muslim Couples', Religions, 5 (2014), 814-33 <https://doi.org/10.3390/rel5030814>

Archer, John, 'Sex Differences in Social Behavior: Are the Social Role and Evolutionary Explanations Compatible?', American Psychologist, 51 (1996), 909-17 $<$ https://doi.org/10.1037/0003066X.51.9.909>

Bornstein, Marc H., 'Parenting and Child Mental Health: A Cross-Cultural Perspective', World Psychiatry, 2013 <https://doi.org/10.1002/wps.20071>

Dufur, Mikaela J., Nyssa C. Howell, Douglas B. Downey, James W. Ainsworth, and Alice J. Lapray, 'Sex Differences in Parenting Behaviors in Single-Mother and Single-Father Households', Journal of Marriage and Family, 72 (2010), 1092-1106 $<$ https://doi.org/10.1111/j.17413737.2010.00752.x>

Kerr, David C.R., Nestor L. Lopez, Sheryl L. Olson, and Arnold J. Sameroff, 'Parental Discipline and Externalizing Behavior Problems in Early Childhood: The Roles of Moral Regulation and Child Gender', Journal of Abnormal Child Psychology, 32 (2004), 369-83 <https://doi.org/10.1023/B:JACP.0000 030291.72775.96>

Kwon, Jae Yung, John L. Oliffe, Joan L. Bottorff, and Mary T. Kelly, 'Heterosexual Gender Relations and Masculinity in Fathers Who Smoke', Research in Nursing and Health, 37 (2014), 391-98 $<$ https://doi.org/10.1002/nur.21614> 
Di Maggio, Rosanna, and Carla Zappulla, 'Mothering, Fathering, and Italian Adolescents' Problem Behaviors and Life Satisfaction: Dimensional and Typological Approach', Journal of Child and Family Studies, 23 (2014), 567-80 $<$ https://doi.org/10.1007/s10826-0139721-6>

Noviati, 'Strategi Pengasuhan Anak oleh Ibu Tunggal dan Bapak Tunggal Mengembangkan Perilaku Etis Pergaulan', Jurnal Kajian Moral Dan Kewarganegaraan, 2 (2015), 1-15

Rahman, Istianah A, 'Hubungan antara Persepsi terhadap Pola Asuh Demokratis Ayah dan Ibu dengan Perilaku Disiplin Remaja', Lentera Pendidikan: Jurnal Ilmu Tarbiyah dan Keguruan, 11 (2008), 69-82 $<$ https://doi.org/10.24252/lp.2008v11n $1 \mathrm{a} 6>$

Rahman, Putri, and Elvi Yusuf, 'Gambaran Pola Asuh Orangtua pada Masyarakat Pesisir Pantai', Predicara, 1 (2012)

Selin, Helaine, and Helaine Selin, Parenting Across Cultures_Childrearing, Motherhood and Fatherhood in Non-Western Cultures, Science Across Cultures: The History of NonWestern Science, 2014 $<$ https://doi.org/10.1007/978-94-0077503-9>

Suciati, Rina, and Ivan Muhammad Agung, 'Perbedaan Ekspresi Emosi pada Orang Batak, Jawa, Melayu dan Minangkabau', Jurnal Psikologi, 2017 $<$ https://doi.org/10.24014/jp.v12i2.323 6>

Sukaidawati, Lisnani, D.K. Pranaji, and Ratna Megawangi, 'Konsep Diri Ibu dan Remaja pada Keluarga Cerai dan Utuh', Jurnal Ilmu Keluarga dan Konsumen, 2016 $<$ https://doi.org/10.24156/jikk.2016.9.1 $.11>$

Wolfe, Anne, Women and Crime, Science News (Macmillan International Higher Education, 1975), CVIII <https://doi.org/10.2307/3960173>

\section{Other references}

Depaiva, Ruth, 'Quality of Fathering and Its Relationship with Family Background, Demographics, and Characteristics of Present Family: A Study of Seventh-Day Adventist Fathers and Fathers From a National Sample' \{unpublished doctoral thesis, Andrews University School of Education, New York, 1998)

Koffi, Lacei R., 'Adolescents' Perceptions of Fathering Factors that Influence Identity Development' \{unpublished doctoral thesis, Texas Woman's University, Denton \& Texas, 2011)

Kuntadi, Heru, 'Gaya Pengambilan Keputusan Ditinjau Dari Tipe Kepribadian' \{unpublished magister thesis, Fakultas Psikologi Universitas Gajah Mada, Yogyakarta, 2004

Littunen, Satu Perälä, 'Cultural Images of a Good Mother and a Good Father in Three Generations' \{unpublished doctoral thesis, Faculty of Education of the University, Jypaskyla, 2004\}

Sipahutar, Rintar, 'Hubungan yang Kaku antara Ayah dan Anak Laki-Lakinya dalam Suku Batak, Kompasiana < https://www.kompasiana.com/rintar_si pahutar/5a73d31ddcad5b632e5a63b2/h ubungan-yang-kaku-antara-ayah-dananak-laki-lakinya-dalam-sukubatak?page $=$ all $>$ accessed 10 March $2018\}$

Widyorini, Endang, 'Perempuan Berbakat dalam Budaya Jawa' \{unpublished magister thesis, Universitas Gadjah Mada, Yogyakarta, 2004\} 